\title{
GEOLOGIC MAP OF THE LYNNDAL 30- BY 60-MINUTE QUADRANGLE, WEST-CENTRAL UTAH
}

\author{
By Earl H. Pampeyan
}

\section{INTRODUCTION}

The Lynndyl 30 - by 60-minute 1:100,000-scale quadrangle is located in west-central Utah at the eastern edge of the Great Basin (fig. 1). The Sevier River, which drains part of the western Colorado Plateaus province, flows through the southeast corner of the quadrangle and terminates at Sevier Lake. The rocks and sediments exposed in the quadrangle represent a fairly complete sequence ranging in age from Middle Proterozoic to Holocene excluding most of the Mesozoic, which is present to the east in the Colorado Plateaus. The presence of major ore deposits in the East Tintic Mountains stimulated geologic interest in this region, and early stratigraphic work was concentrated around the Tintic ore deposits. Tower and Smith (1899), Crane (1917), and Lindgren and Loughlin (1919) established the basic geologic framework that stood for many years. Subsequent updating of the stratigraphy by Morris and Lovering (1961; 1979), Morris (1978), and Christie-Blick (1982) and the regional structure by Morris (1983) and Christie-Blick (1983) is shown on this map.

Geologic data for the bedrock areas of the Lynndyl 30by 60 -minute quadrangle were compiled from a variety of published and unpublished sources, many of which were used by Morris (1978) in his compilation of the Delta $2^{\circ}$ quadrangle (see index to geologic mapping, fig. 2). The intervening areas of surficial deposits were mapped by the author largely in a reconnaissance fashion between 1981 and 1983, with the exception of an area east of Lynndyl that was mapped in great detail by Varnes and Van Horn (1984). The physical properties of bedrock and surficial units were not determined for this map, but some soils engineering data are available in public documents, for example, Utah State Department of Highways (1971), Stott (1977), and numerous private site investigations reports prepared for the Intermountain Power Agency and the U.S. Air Force, pertaining to the Intermountain Power Project site and the M-X Missile siting scheme, respectively. The ground-water hydrology and its relation to surficial deposits in a large part of the map area has been described by Holmes (1984).

The quality of geologic source materials used in this map is shown in the reliability diagram (fig. 3), mainly to indicate the state of geologic knowledge in the quadrangle and where future geologic studies might best be directed. The rocks have not changed in historic time but interpretations based on them have, and ongoing improvements in access, mapping and laboratory techniques, and topographic base maps will benefit future interpretations.

Map units selected for use on this map correspond as nearly as possible to a division of geologic periods into epochs. The map-unit boundaries, in most cases, match epoch boundaries, but where a formation boundary straddles a time boundary the formation is arbitrarily included in one or the other adjacent unit, and owing to map scale and thickness of map units, the map pattern is not noticeably different than if the formation had been included in the other adjacent map unit. An attempt at consistency in usage is made, but differences in mapping style and interpretation in the source materials inadvertantly may cause some misidentifications or misassignments. In some cases the map units consist of a single formally recognized formation and in other cases two or more formations.

The igneous rocks are separated into intrusive and extrusive units, and--where not formally named--are informally named to indicate their distribution throughout the quadrangle; the correlations are approximate and based on the available physical evidence and sparse radiometric dates. The igneous units in the Keg, Simpson, and Desert Mountains and in the area around Sage Valley need to be studied in detail before more meaningful relations can be established throughout the quadrangle.

\section{GEOLOGIC SETTING}

The geologic setting of the region including the Lynndyl quadrangle is controlled by the regional structure, and the reader is referred to papers by Morris (1983) and Christie-Blick (1983) for a comprehensive description of the regional structure. Paleozoic rocks herein are separated into three "facies" determined by their position relative to two major thrust faults, the Tintic Valley and Sheeprock thrusts (fig. 4). The Tintic Valley thrust is exposed in the east half of the Gilson Mountains and south end of the East Tintic Mountains, and its position under Tintic Valley is dictated by significant facies changes in Cambrian to Devonian rocks between the East and West Tintic ranges. The Sheeprock thrust is exposed in the West Tintic and Sheeprock Mountains and its presence under the Sand Hills, Black Mountains, and Jericho Ridge is indicated by lithologic differences in Lower and Middle Cambrian rocks and proximity of Pennsylvanian rocks. The Canyon Range thrust is considered to be part of the Sheeprock thrust displaced along the Leamington transcurrent fault (Morris, 1983). (The Canyon Range thrust fault and the Canyon Range 

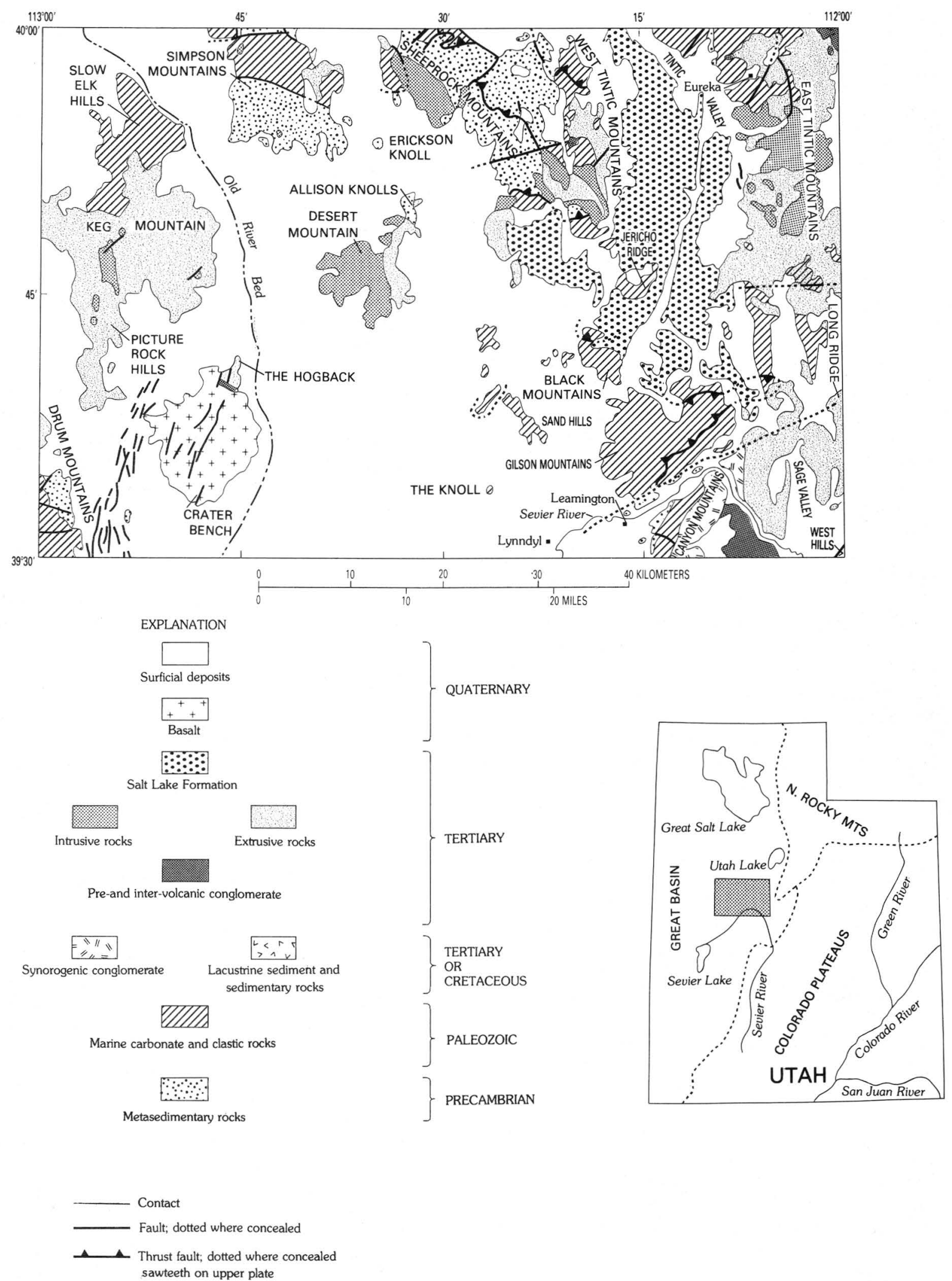

Figure 1.-Generalized geologic map of the Lynndyl 30- by 60-minute quadrangle, and index map of Utah showing location of quadrangle (shaded) and other pertinent features. 


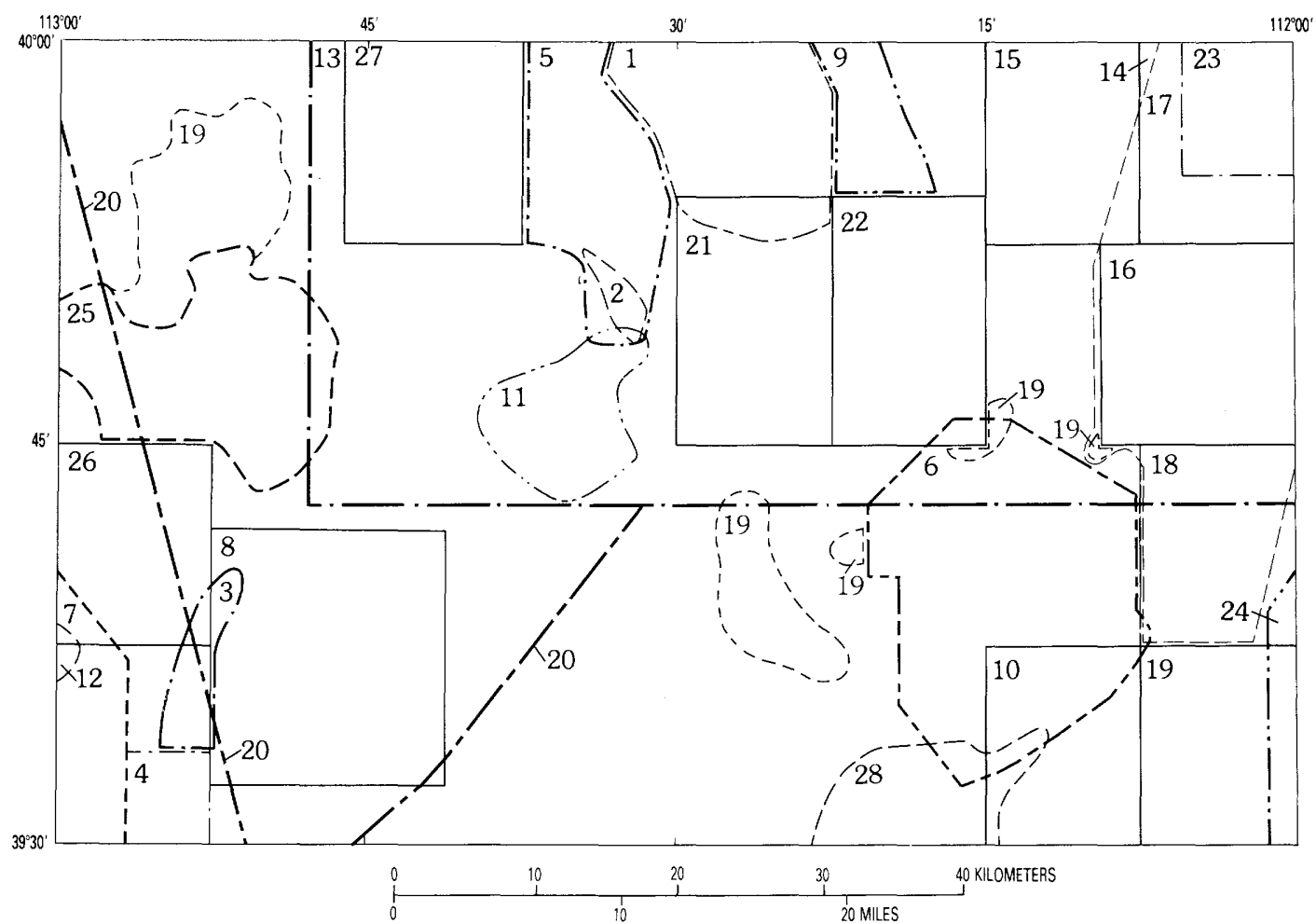

1. Blick (1979) and Christie-Blick (1982; 1983)

2. Blick (1979)

3. Faults from Bucknam and Anderson (1979a) and R.C. Bucknam, unpubl. data, 1982, with additions

4. Faults from Bucknam and Anderson (1979a) and Crone (1983), with additions

5. Cohenour (1959), modified by Morris (1978), with additions

6. Costain (1960) and Morris (1978)

7. Dommer (1980), with additions and modifications

8. Galyardt and Rush (1981), with additions and modifications

9. Groff (1959), modified by Morris (1978), with additions

10. Higgins (1982)

11. Kattelman (1968) and Rees and others (1973), modified by Morris (1978)

12. Lindsey (1979)

13. Mabey and Morris (1967) and Morris (1977)

14. Morris (1964a)

Figure 2.-Index to geologic mapping, Lynndyl 30- by 60 -minute quadrangle, Utah. (Bedrock and locally surficial geology compiled or adapted from these sources.)

Formation of Stolle (1978) have their type areas in the Canyon Mountains, a physiographic unit known in the geologic literature as the Canyon Range.) The Frisco-Wah Wah thrust is not exposed in the Lynndyl quadrangle but its presence is required to explain lithologic differences between lower Paleozoic rocks of the western part of the quadrangle and those just beyond the west edge. The Precambrian to Middle Cambrian rocks of the part of the Drum Mountains in the Lynndyl quadrangle, however, are the same as and included with those of the Sheeprock plate.

The Proterozoic section, most complete in the Sheeprock Mountains where it is more than 6,500 m thick (Christie-Blick, 1982), consists of metasedimentary rocks that include a thick section of tillite. Overlying the
Proterozoic rocks along the east edge of the quadrangle is a Paleozoic sedimentary section that exceeds $10,000 \mathrm{~m}$, more than half of which is Pennsylvanian and Permian Oquirrh Formation (Morris, 1964a, 1964b, 1977) (fig. 5). Westward across the quadrangle, upper Paleozoic rocks are not exposed, but lower Paleozoic rocks are represented by about $4,200 \mathrm{~m}$ of Cambrian and Ordovician beds (Dommer, 1980), almost twice the thickness of equivalent rocks at the east edge of the quadrangle. The westward increase in thickness of Paleozoic rocks toward the axis of the Cordilleran geosyncline is emphasized by foreshortening across several major thrust fauits. Unconformably above the Paleozoic rocks in the southeast corner of the quadrangle is as much as $1,000 \mathrm{~m}$ of coarse conglomerate (Higgins, 1982) resulting from thrusting in 


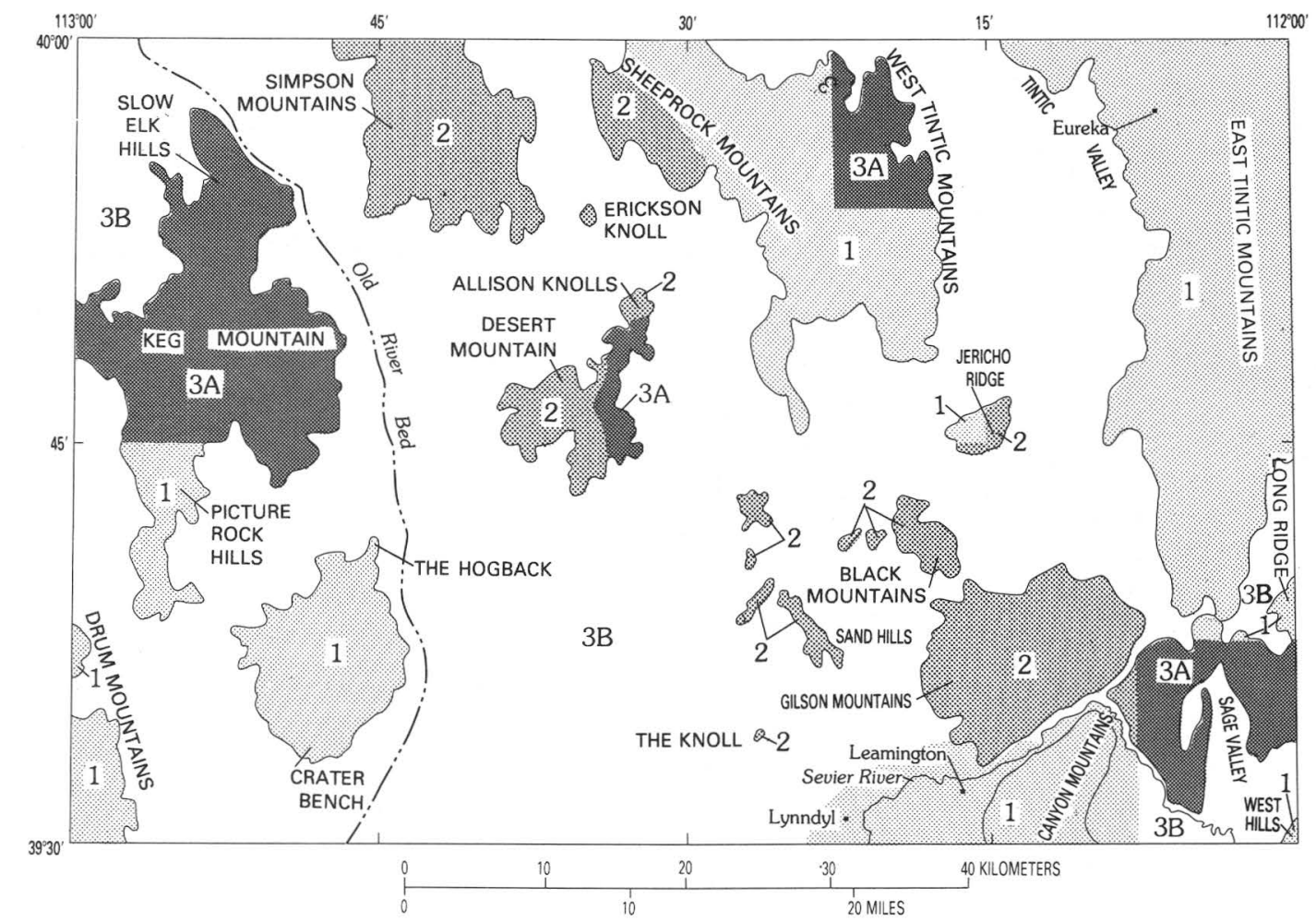

Figure 3.-Geologic data used in this map were compiled from a variety of sources ranging from detailed to rapid reconnaissance field studies plotted on good, large-scale $(1: 24,000)$ to poor, small-scale $(1: 250,000)$ topographic maps and aerial photographs. This diagram is an assessment of the overall quality of the geologic materials as they pertain to this $1: 100,000$-scale geologic map.

EXPLANATION

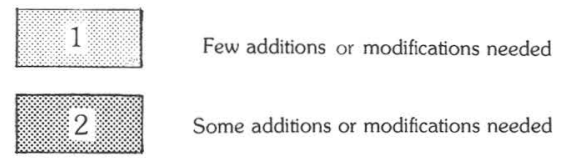

Late Cretaceous or early Tertiary time. This conglomerate is succeeded by--and in places equivalent to--finer fluviatile conglomerates and lacustrine limestones, the latter being widely exposed east of the quadrangle. Other local deposits of fluviatile conglomerate are present under and interlayered with a succession of Eocene to Miocene extrusive rocks widespread in the quadrangle; intrusive rocks closely related to the extrusive rocks are present in much of the area and in places cut the major faults. This period of igneous activity was followed by regional deposition of a thick sequence of fine-grained lacustrine deposits with volcanic ash interbeds-the Miocene and Pliocene Salt Lake Formation. In Pleistocene time local eruptions of basaltic lava and ash in and south of the quadrangle occurred during the accumulation of Lake Bonneville deposits. Although the major tectonic events preceeded late Cenozoic time, late Pleistocene or Holocene faulting is manifested by a swarm of faults that cut Lake Bonneville deposits in the southwest corner of the area (Bucknam and Anderson, 1979b; Crone, 1983).

In general, igneous rocks of the east half of the quadrangle--and those west of the quadrangle--have been studied in greater detail than those in the west half, mainly because of their relations to ore deposits. Both

\section{A Many additions or modifications needed}

3B Many additions and modifications needed

intrusive and extrusive rocks are predominantly of intermediate composition and consist of monzonite and quartz monzonite stocks and latite and quartz latite flows and tuffs, with some acidic and basic rocks present locally.

Lacustrine deposits of the Salt Lake Formation crop out in the eastern half of the Lynndyl quadrangle above the Bonneville shoreline, from about $1,567 \mathrm{~m}$ up to about $1,920 \mathrm{~m}$. Below the Bonneville shoreline, which ranges from an elevation of about $1,559 \mathrm{~m}$ to $1,593 \mathrm{~m}$ across the map area, the Salt Lake deposits either are covered, eroded, or reworked and indistinguishable from finegrained Lake Bonneville deposits. An isolated exposure of Salt Lake deposits is present at the south edge of Crater Bench in a quarry opened in 1982 to supply ballast for the spur railroad between Lynndyl and the Intermountain Power Project site. There, reddish-brown to pink, fine clastic sediments are unconformably overlain by the Basalt of Crater Bench. These beds, lithologically identical to the Salt Lake deposits north of the Gilson Mountains, appear to be a remnant of the Salt Lake Formation protected from erosion in Lake Bonneville by the basalt cap. Crater Bench is surrounded by wave-worked basalt scree and is capped with patches of fossilferous fine-grained deposits of Lake Bonneville. Three sections of Lake Bonneville 


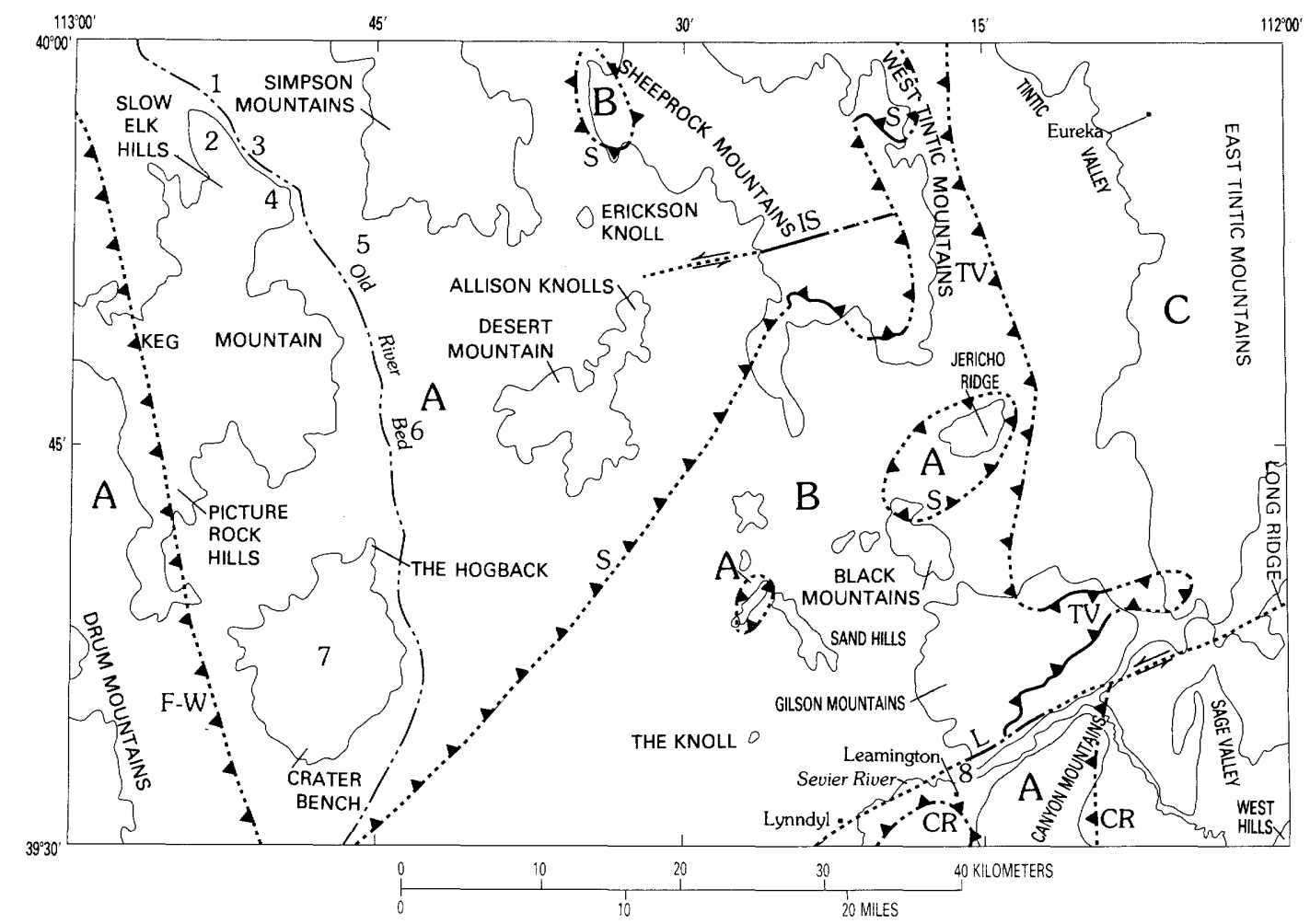

Figure 4. Generalized map showing structural framework of the Lynndyl quadrangle as determined from distribution of pre-Mesozoic sedimentary rocks, after Morris (1983). F-W, Frisco-Wah Wah thrust; IS, Indian Spring transcurrent fault; S, Sheeprock thrust; TV, Tintic Valley thrust; L, Leamington transcurrent fault; CR, Canyon Range (= Sheeprock) thrust. Faults are dotted where inferred; sawteeth are on upper plate of thrust faults; arrows indicate relative movement. The Sheeprock, Tintic Valley, and Leamington faults form the boundaries of three Paleozoic lithologic facies, A, B, and C (see correlation of map units). Also shown are localities of geomorphic features described by Gilbert (1890): 1, Lower River Bed section (p. 189-191); 2, Reservoir Butte (p. 148-149, pls. VII, XXIV, XXV, XXXI); 3, Upper River Bed section (p. 194-196, pl. XXXII); 4, Cup Butte (p. 55, 138, pls. VI, XXIII, XXXI); 5, The Snowplow (p. 138, 147-148, pls. VII, XIX, XXIII, XXXI); 6, Old River Bed (p. 181-184, pl. XXXXI); 7, Fumarole Butte (p. 332-335, pl. XXXI); 8, Leamington section (p. 192-193).

deposits, originally used by Gilbert (1890) to derive his theory of lake-level oscillations, lie within the Lynndyl quadrangle; the Upper and Lower River Bed and Leamington localities (fig. 4). Modern studies by Varnes and Van Horn (1961) and Currey and others (1983) have reinterpreted the history of Lake Bonneville on the basis of these same stratigraphic sections. The quadrangle also contains lacustrine geomorphic features described by Gilbert (1890), for example, Reservoir Butte (Table Mountain on modern maps), Cup Butte, The Snowplow, and the Old River Bed (fig. 4).

Metallic mineral resources of the quadrangle consist chiefly of gold, silver, lead, and zinc with lesser amounts of copper, manganese, and tungsten, and traces of beryllium, thorium, samarian, and uranium. Major baseand precious-metal ore bodies in the East Tintic Mountains have been worked since the early 1870's (Billingsley and Crane, 1933); smaller deposits in the West Tintic, Sheeprock, and Simpson Mountains and at Desert Mountain also have been productive. The base- and precious-metal deposits occur as narrow veins in igneous rocks and as replacement veins and bodies in carbonate rocks, and are thought to represent the culmination of Tertiary igneous activity. Thorium-and samarium-bearing minerals are found in pegmatite dikes cutting granite, and beryl is disseminated in the same granite in the Sheeprock Mountains (Cohenour, 1959). The uranium appears to be localized in fluorite, which occurs in some base-metal veins. For detailed information on the history of mining and the stratigraphic and structural controls and mineralogy of these ore deposits the reader is referred to papers by Lindgren and Loughlin (1919), Butler and others (1920), Billingsley and Crane (1933), Stringham (1942), Cohenour (1959), and Morris (1968). The world's largest beryllium deposits are in the Thomas Range, about $15 \mathrm{~km}$ west of the quadrangle, and this range also contains well-known deposits of topaz (Staatz and Carr, 1964.

Nonmetallic resources of the quadrangle are halloysite clay, high-purity limestone, high-silica quartzite, and construction materials. The major United States source of catalytic grade halloysite is just south of Eureka where it occurs in pipelike bodies in lower Paleozoic limestone near the monzonite porphyry contact. Summary statements on the metallic and nonmetallic commodities of this area are found in a report on the mineral resources of Utah (U.S. Geological Survey, 1964). 


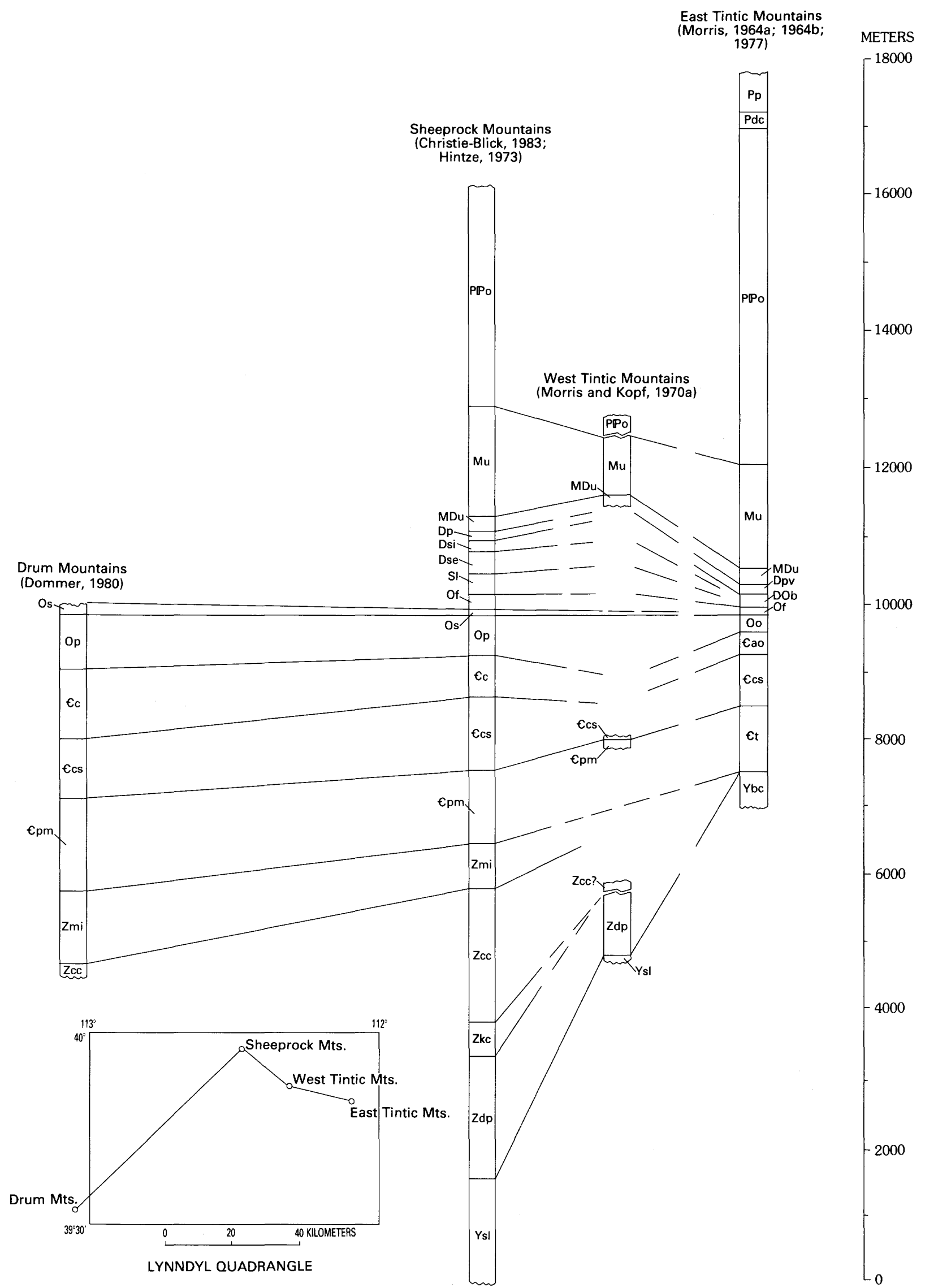

Figure 5. Stratigraphic sections across the Lynndyl 30- by 60-minute quadrangle, Utah. See description of map units for explanation of letter symbols. 


\section{REFERENCES CITED}

Armstrong, R.L., 1970, Geochronology of Tertiary igneous rocks, eastern Great Basin and Range Province, western Utah, eastern Nevada, and vicinity, U.S.A.: Geochimica et Cosmochimica Acta, v. 34, no. 2, p. 203-232.

Billingsley, Paul, and Crane, G.W., 1933, Tintic mining district: International Geologic Congress, 16th, Washington, D.C., 1933, Guidebook 17, p. 101-124.

Blick, N.H., 1979, Stratigraphic, structural and paleographic interpretation of upper Proterozoic glaciogenic rocks in the Sevier orogenic belt, northwestern Utah (Ph.D. thesis): University of California, Santa Barbara, 633 p.

Bucknam, R.C., and Anderson, R.E., 1979a, Map of scarps on consolidated sediments, Delta $1^{\circ} \times 2^{\circ}$ quadrangle, Utah: U.S. Geological Survey Open-File Report 79-366, scale 1:250,000.

$1979 b$, Estimation of fault-scarp ages from a scarpheight--slope-angle relationship: Geology, v. 7, p. 1114.

Butler, B.S., Loughlin, G.F., Heikes, V.C., and others, 1920, The ore deposits of Utah: U.S. Geological Survey Professional Paper 111, $672 \mathrm{p}$.

Campbell, J.A., 1979, Middle to late Cenozoic stratigraphy and structural development of the Canyon Range, central Utah: Utah Geology, v. 6, no. 1, p. 1-16.

Christiansen, F.W., 1952, Structure and stratigraphy of the Canyon Range, central Utah: Geological Society of America Bulletin, v. 63, no. 7, p. 717-740.

Christie-Blick, Nicholas, 1982, Upper Proterozoic and Lower Cambrian rocks of the Sheeprock Mountains, Utah: Regional correlation and significance: Geological Society of America Bulletin, v. 93, no. 8, p. $735-750$.

1983, Structural geology of the southern Sheeprock Mountains: Regional significance: Geological Society of America Memoir 157, p. 101124.

Cohenour, R.E., 1959, Sheeprock Mountains, Tooele and Juab Counties, Utah: Utah Geological and Mineralogical Survey Bulletin 63, 200 p., pl. 1, scale $1: 135,000$

Costain, J.K., 1960, Geology of the Gilson Mountains and vicinity, Juab County, Utah (Ph.D. thesis): University of Utah, Salt Lake City, 139 p.,pl. 1, scale 1:40,877.

Crane, G.W., 1917, Geology of the ore deposits of the Tintic mining district, Utah: American Institute of Mining Engineers, Transactions, v. 54, p. 342-355.

Crone, A.J., ed., 1983, Paleoseismicity along the Wasatch fault and adjacent areas, central Utah: Utah Geological and Mineral Survey Special Studies 62, pt. IV (Geologic excursions in neotectonics and engineering geology in Utah), p. 1-45.

Currey, D.R., 1982, Lake Bonneville: selected features of relevance to neotectonic analysis: U.S. Geological Survey Open-File Report 82-1070, scale 1:500,000.

Currey, D.R., Oviatt, C.G., Plyler, G.B., 1983, Lake Bonneville stratigraphy, geomorphology, and isostatic deformation in west-central Utah: Utah Geological and Mineral Survey Special Studies 62, p. 63-82.

Dommer, M.L., 1980, The geology of the Drum Mountains, Millard and Juab Counties, Utah: Brigham
Young University Geology Studies, v. 27, pt. 3, p 55-72, plates.

Erickson, M.P., 1963, Volcanic geology of western Juab County, Utah, in Beryllium and uranium mineralization in western Juab County, Utah: Utah Geological Society Guidebook, no. 17, p. 23-35.

Galyardt, G.L., and Rush, F.E., 1981, Geologic map of the Crater Springs Known Geothermal Resources Area and vicinity, Juab and Millard Counties, Utah: U.S. Geological Survey Miscellaneous Investigations Series Map I-1297, scale 1:24,000.

Gilbert, G.K., 1890, Lake Bonneville: U.S. Geological Survey Monograph 1, $448 \mathrm{p}$.

Goode, H.D., 1961, Quaternary system, in Morris, H.T., and Lovering, T.S., Stratigraphy of the East Tintic Mountains, Utah: U.S. Geological Survey Professional Paper 361, p. 129-138.

Groff, S.L., 1959, Geology of the West Tintic Range and vicinity, Tooele and Juab Counties, Utah (Ph.D. thesis): University of Utah, Salt Lake City, 183 p., pl. 1 , scale $1: 20,439$.

Higgins, J.M., 1982, Geology of the Champlin Peak quadrangle, Juab and Millard Counties, Utah: Brigham Young University Geology Studies, v. 29, pt. 2 , p. $40-58$, scale $1: 24,000$.

Hintze, L.F., 1973, Geologic history of Utah: Brigham Young University Geology Studies, v. 20, pt. 3, $181 \mathrm{p}$.

Hogg, N.C., 1972, Shoshonitic lavas in west central Utah: Brigham Young University Geology Studies, v. 19, pt. 2, p. 133-184.

Holmes, W.F., 1984, Ground-water hydrology and projected effects of ground-water withdrawls in the Sevier Desert, Utah: Utah Department of Natural Resources, Technical Publication No. 79, 54 p.

Izett, G.A., and Wilcox, R.E., 1982, Map showing localities and inferred distribution of the Huckleberry Ridge, Mesa Falls, and Lava Creek ash beds (Pearlette Family Ash Beds) of Pliocene and Pleistocene age in the western United States and southern Canada: U.S. Geological Survey Miscellaneous Investigations Series Map I-1325, scale $1: 4,000,000$.

Kattelman, D.E., 1968, Geology of the Desert Mountain intrusives, Juab County, Utah: Brigham Young University Geology Studies, V. 15, pt. 1, p. 85-107.

Krusi, A.P., and Patterson, R.H., 1980, Problems in Lake Bonneville stratigraphic relationships in the northern Sevier basin revealed by exploratory trenching, in Proceedings of Conference $\mathrm{X}$, Earthquake hazards along the Wasatch-Sierra Nevada frontal fault zones: U.S. Geological Survey Open-File Report 80-801, p. 509-518.

Laughlin, A.W., Lovering, T.S., and Mauger, R.L., 1969, Age of some Tertiary igneous rocks from the East Tintic district, Utah: Economic Geology, v. 64, no. 8 , p. 915-918.

Lindgren, Waldemar, and Loughlin, G.F., 1919, Geology and ore deposits of the Tintic mining district, Utah: U.S. Geological Survey Professional Paper 107, 282 p.

Lindsey, D.A., 1979, Geologic map and cross-sections of Tertiary rocks in the Thomas Range and northern Drum Mountains, Juab County, Utah: U.S. 
Geological Survey Miscellaneous Investigation Series Map 1-1176, scale 1:62,500.

1982, Tertiary volcanic rocks and uranium in the Thomas Range and northern Drum Mountains, Juab County, Utah: U.S. Geological Survey Professional Paper 1221, $71 \mathrm{p}$.

Lindsey, D.A., Naeser, C.W., and Shawe, D.R., 1975 Age of volcanism, intrusion, and mineralization in the Thomas Range, Keg Mountain, and Desert Mountain, western Utah: U.S. Geological Survey Journal of Research, v. 3, no. 5, p. 597-604.

Mabey, D.R., and Morris, H.T., 1967, Geologic interpretation of gravity and aeromagnetic maps of Tintic Valley and adjacent areas, Tooele and Juab Counties, Utah: U.S. Geological Survey Professional Paper 516-D, 10 p., 1 pl., scale 1:125,000.

Mehnert, H.H., Rowley, P.D., and Lipman, P.W., 1978, $\mathrm{K}-\mathrm{Ar}$ ages and geothermal implications of young rhyolites in west-central Utah: Isochron West, no. 21, p. 3-7.

Morris, H.T., 1964a, Geology of the Eureka quadrangle, Utah and Juab Counties, Utah: U.S. Geological Survey Bulletin 1142-K, p. K1-K29, scale 1:24,000.

1964b, Geology of the Tintic Junction quadrangle, Tooele, Juab, and Utah Counties, Utah: U.S. Geological Survey Bulletin 1142-L, p. L1-L23, scale 1:24,000.

1968, The main Tintic mining district, Utah, in Ridge, J.D., ed., Ore deposits of the United States, 1933-1967 (Graton-Sales Volume), pt. 2: New York, American Institute of Mining, Metallurgical, and Petroleum Engineers, p. 1043-1073.

1975, Geologic map and sections of the Tintic Mountain quadrangle and adjacent part of the McIntyre quadrangle, Juab and Utah Counties, Utah: U.S. Geological Survey Miscellaneous Investigations Map I-883, scale 1:24,000.

1977, Geologic map and sections of the Furner Ridge quadrangle, Juab County, Utah: U.S. Geological Survey Miscellaneous Investigations Map I1045, scale 1:24,000.

1978, Preliminary geologic map of Delta $2^{\circ}$ quadrangle, west-central Utah: U.S. Geological Survey Open-File Report 78-705, scale 1:250,000.

1983 , Interrelations of thrust and transcurrent faults in the central Sevier orogenic belt near Leamington, Utah: Geological Society of America Memoir 157, p. 75-81.

Morris, H.T., and Kopf, R.W., 1967, Breccia pipes in the West Tintic and Sheeprock Mountains, Utah in Geological Survey Research 1967: U.S. Geological Survey Professional Paper 575-C, p. C66-71.

1970a, Preliminary geologic map and cross sections of the Cherry Creek quadrangle and adjacent part of the Dutch Peak quadrangle, Juab County, Utah: U.S. Geological Survey Open-File Map 70-233, scale 1:24,000.

$1970 \mathrm{~b}$, Preliminary geologic map and cross section of the Maple Peak quadrangle and adjacent part of the Sabie Mountain quadrangle, Juab County, Utah: U.S. Geological Survey Open-File Map 70-234, scale $1: 24,000$

Morris, H.T. and Lovering, T.S., 1961, Stratigraphy of the East Tintic Mountains, Utah, with a section on
Quaternary deposits by H.D. Goode: U.S. Geological Survey Professional Paper 361, 145 p.

1979, General geology and mines of the East Tintic mining district, Utah and Juab Counties, Utah: U.S. Geological Survey Professional Paper 1024, 203 p.

Morris, H.T., Douglass, R.C., and Kopf, R.W., 1977, Stratigraphy and microfaunas of the Oquirrh Group in the southern East Tintic Mountains, Utah: U.S. Geological Survey Professional Paper 1025, 22 p.

Muessig, S.J., 1951a, Geology of a part of Long Ridge, Utah (Ph.D. thesis): Ohio State University, Columbus, 213 p.

1951b, Eocene volcanism in central Utah: Science, v. 114, p. 234.

Peterson, J.B.; and Nash, W.P., 1980, Geology and petrology of the Fumarole Butte volcanic complex, Utah, in Studies in late Cenozoic volcanism in westcentral Utah: Utah Geological and Mineral Survey Special Studies 52, pt. II, p. 34-58.

Rees, D.C., Erickson, M.P., and Whelan, J.A., 1973, Geology and diatremes of Desert Mountain, Utah: Utah Geological and Mineralogical Survey Special Studies 42, 12 p., scale 1:24,000.

Shawe, D.R., 1972, Reconnaissance geology and mineral potential of the Thomas, Keg, and Desert Calderas, central Juab County, Utah, in Geological Survey Research 1972: U.S. Geological Survey Professional Paper 800-B, p. B67-B77.

Staatz, M.H., and Carr, W.J., 1964, Geology and mineral deposits of the Thomas and Dugway Ranges, Juab and Tooele Counties, Utah: U.S. Geological Survey Professional Paper 415, $188 \mathrm{p}$.

Staub, A.M., 1975, Geology of the Picture Rock Hills quadrangle, southwestern Keg Mountain, Juab County, Utah (M.S. thesis): University of Utah, Salt Lake City, $87 \mathrm{p}$.

Stolle, J.M., 1978, Stratigraphy of the Lower Tertiary and Upper Cretaceous(?) continental strata in the Canyon Range, Juab County, Utah: Brigham Young University Geology Studies, v. 25, pt. 3, 117-139.

Stott, L.H., 1977, Soil Survey of Delta area Utah, part of Millard County: U.S. Department of Agriculture, Soil Conservation Service, $77 \mathrm{p}$.

Stringham, B.F., 1942, Mineralization in the West Tintic mining district, Utah: Geological Society of America Bulletin, v. 53 , no. 2, p. $267-290$

Thomas, G.H., 1958, Geology of the Indian Springs quadrangle, Tooele and Juab Counties, Utah: Brigham Young University Research Studies, Geology Series, v. 5, no. 4, 35 p., scale 1:27,800.

Tower, G.W., and Smith, G.O., 1899, Geology and mining industry of the Tintic district, Utah: U.S. Geological Survey 19th Annual Report (1897-98), pt. 3, p. 601-676.

U.S. Geological Survey, 1964, Mineral and water resources of Utah: Prepared at the request of Senator Frank E. Moss by the U.S. Geological Survey in cooperation with the Utah Geological and Mineralogical Survey and Utah Water and Power Board, U.S. Government Printing Office, Washington, D.C., 275 p.

Utah State Department of Highways, 1971, Materials inventory, Millard County: Utah State Dept. 
Highways, Materials \& Research Div., Materials Inventory Section, $24 \mathrm{p}$.

Varnes, D.J., and Van Horn, Richard, 1961, A reinterpretation of two of G.K. Gilbert's Lake Bonneville sections, Utah, in Geological Survey
Research 1961: U.S. Geological Survey Professional Paper 424-C, p. C-98-C99

1984, Surficial geologic map of the Oak City area, Millard County, Utah: U.S. Geological Survey OpenFile Report 84-115, scale 1:31,680. 

